IRA-International Journal of Technology \& Engineering ISSN 2455-4480; Vol.05, Issue 03 (2016)

Pg. no. 77-89

Institute of Research Advances

http://research-advances.org/index.php/IRAJTE

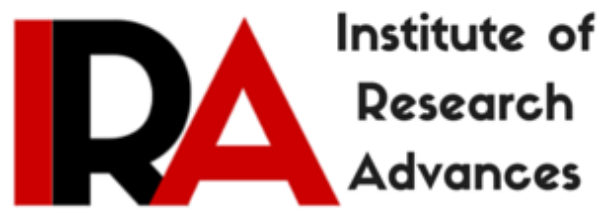

\title{
Experimental Studies on Reinforced Concrete and Ferrocement Beams
}

\section{N. Jayaramappa}

Associate Professor, Department of Civil Engineering, UVCE

Jnanabharathi Campus Bangalore 560056, India.

Type of Reviewed: Peer Reviewed.

DOI: http://dx.doi.org/10.21013/jte.v5.n3.p4

\section{How to cite this paper:}

Jayaramappa, N. (2016). Experimental Studies on Reinforced Concrete and Ferrocement Beams. IRA-International Journal of Technology \& Engineering (ISSN 2455-4480), 5(3), 77-89. doi:http://dx.doi.org/10.21013/jte.v5.n3.p4

(C) Institute of Research Advances

\section{(cc) EY-NO}

This work is licensed under a Creative Commons Attribution-Non Commercial 4.0 International License subject to proper citation to the publication source of the work.

Disclaimer: The scholarly papers as reviewed and published by the Institute of Research Advances (IRA) are the views and opinions of their respective authors and are not the views or opinions of the IRA. The IRA disclaims of any harm or loss caused due to the published content to any party. 


\section{ABSTRACT}

Arch structures have been utilized through the ages, beginning in the ancient civilizations of Greece, Egypt and Rome, to present day with their common use in bridges. Arches are well known for the ability to carry loads spanning large areas. Also now a day's Ferrocement is being used extensively for various applications where use of normal concrete is hard to fulfil the present day requirements. In this paper experimental studies are carried out to understand the flexural behaviour of Reinforced concrete beams of grade M20 with HYSD reinforcement and Ferrocement hollow beams of cement to sand ratio of 1:3 and water cement ratio of 0.4. A total of four beams were cast in which two are straight beams and another two are arched beams. In that two straight beam, one is reinforced concrete beam with minimum reinforcement and another one is Ferrocement hollow beam and in two arch beams, one is reinforced concrete beam and other is Ferrocement hollow beam. All beams are rectangular in cross-section of size $200 \times 200 \mathrm{~mm}$ and the span length is $2500 \mathrm{~mm}$. The arch beam is provided with a rise at centre of $0.8 \mathrm{~m}$. The Ferrocement beam is made of mortar with hollow cross section using hexagonal wire mesh with thickness of $40 \mathrm{~mm}$ and all the specimens are cured for 28 days. Flexural tests are carried out on conventional RC beam and Ferrocement hollow beams for simply supported condition. The test results are presented in terms of load deflection behaviour, ultimate load, cracking load and crack pattern with respect to reinforced concrete beam and Ferrocement hollow beam.

Key Words: Ferrocement, arch structures, flexural behaviour and hexagonal wire mesh.

\section{Introduction}

\subsection{Arch Structures}

Arch structures have been used in construction since the ancient civilizations of Greece and Rome. These civilizations utilized arches in order to span large areas and carry loads which could otherwise not be possible with a column and beam approach. However the arch was also utilized for its aesthetic contribution to structures, not just its structural advantages. The arch is designed in order to produce a system which transports the applied loads to supports primarily through compression stresses in the arch, eliminating the possibility of tensile stresses occurring within the chosen material. This is achieved, to some degree, through design of the arch shape to match as closely as possible to the line of thrust within the arch.

Arches are intrinsically efficient because they carry a large share of their applied loads in compression. The geometric form of an arch is typically chosen such that the centroidal axis of the arch coincides with the line of action of force, or pressure line, of a given set of permanent loads .Shaping arches in this way allows them to carry permanent loads in a state of pure compression. Because concrete is strong in compression and weak in tension, carrying permanent loads in compression is considered to be a more economical use of material than carrying permanent loads in bending. To carry tensile stresses that arise due to bending, concrete members must rely on longitudinal steel reinforcement to maintain equilibrium. Thus the required amount of steel and concrete is generally lower in arches than in beams for permanent loads.

\subsection{Ferrocement}

Ferrocement is a form of reinforced concrete using closely spaced multiple layers of mesh and/or small diameter rods completely infiltrated with, or encapsulated in, mortar. The most common type of reinforcement is steel mesh. The aim was to find an alternative to timber, which was usually damaged easily by water or dampness. However, from making boats, Ferrocement soon was used for roofing and also found a wide variety of applications in the marine sector, agriculture, water supply and sanitation as well as in the energy sector. It was found suitable for making storage bins and lining irrigation canals, constructing water tanks, septic tanks, sewerages and latrines. The construction of Ferrocement shells has been found attractive in many developing countries. 
The most significant contribution of Ferrocement is that most of the structures that are made of steel can also be constructed in Ferrocement. Structures constructed in Ferrocement will resist corrosion fully with nil/negligible maintenance. Ferrocement section in form of 'I', tee channel or angle as in case of steel can be manufactured with many added advantages. Even Ferrocement anticorrosion treatment can be carried out effectively on existing steel structure surfaces.

\section{Materials and Methodology}

2.1 In the present work, ordinary Portland cement of 53 grade (Zuari cement) conforming to IS 8112:1989 is been used, locally obtained natural river sand is used as the fine aggregate in the concrete mixes. The granite metal jelly $20 \mathrm{~mm}$ and down size is used. Coarse aggregate crushed granite of $20 \mathrm{~mm}$ maximum size and retained on IS480 sieves have been used. The sieve analysis of coarse aggregate conforms to the specifications of IS 383:1970 for graded aggregates and specific gravity. Water used for mixing and curing shall be clean and free from injurious amounts of oils, acids, alkalis, salts, sugar, organic materials or other substances that may deleterious to concrete or steel. HYSD bars of 10, 8 and $6 \mathrm{~mm}$ diameter and Hexagonal wire mesh (chicken mesh) have been used. High yield strength deformed bars conforming to IS: 1786 (grade Fe 500) have been used. These bars were tested for tensile strength. Commonly hexagonal type of wire mesh are used in practice and the diameter of wire is 0.45 $\mathrm{mm}$.

\subsection{Mix Proportions}

For the present work concrete of grade M20 is adopted. The mix design is obtained as per standard procedure as outlined in IS 10262:2009.

\subsection{Strength Tests of Concrete}

Compressive strength, flexural strength test and split tensile strength tests were carried out.

\section{Preparation of Beam Specimens for Testing}

Experimental studies are carried out to understand the flexural behavior of Reinforced concrete beams of grade M20 and HYSD reinforcement and Ferrocement hollow beams of cement to sand ratio of $1: 3$.

A total of four beams were cast in which two are straight beams and another two are arched beams. In that two straight beam, one is reinforced concrete beam with minimum reinforcement and another one is ferrocement hollow beam and in two arch beams, one is reinforced concrete beam and other is ferrocement hollow beam. All beams are rectangular in cross-section of size $200 \times 200 \mathrm{~mm}$ and the overall length is $2500 \mathrm{~mm}$. The arch beam is provided with a rise of $0.8 \mathrm{~m}$. The ferrocement beam is made of mortar with hollow cross section using hexagonal wire mesh with thickness of $40 \mathrm{~mm}$ and all the specimens are cured for 28 days.

The reinforcement details of beams are as follows;

\subsection{Conventional Beam}

2 bars of $10 \mathrm{~mm}$ diameter at bottom and 2 bars of $10 \mathrm{~mm}$ diameter at top as anchor bars of 500 grades were placed. $8 \mathrm{~mm}$ diameter $2 \mathrm{LVS}$ at $200 \mathrm{~mm} \mathrm{c} / \mathrm{c}$ spacing as a shear reinforcement was adopted to prepare the reinforcement cage.

\subsection{Ferrocement Hollow Beams}

2 bars of $6 \mathrm{~mm}$ diameter at bottom and 2 bars of $6 \mathrm{~mm}$ diameter at top as anchor bars of 500 grades were placed. $6 \mathrm{~mm}$ diameter $2 \mathrm{LVS}$ at $200 \mathrm{~mm} \mathrm{c} / \mathrm{c}$ spacing as a shear reinforcement was adopted to prepare the reinforcement cage. 
The strain gauges are installed to measure the strain under loading the strain gauges of $350 \mathrm{Ohms}$ were attached to the bottom reinforcement and concrete surface at the place where maximum strain occurs.

Casting of conventional and ferrocement beams are as shown in figure $1 \& 2$
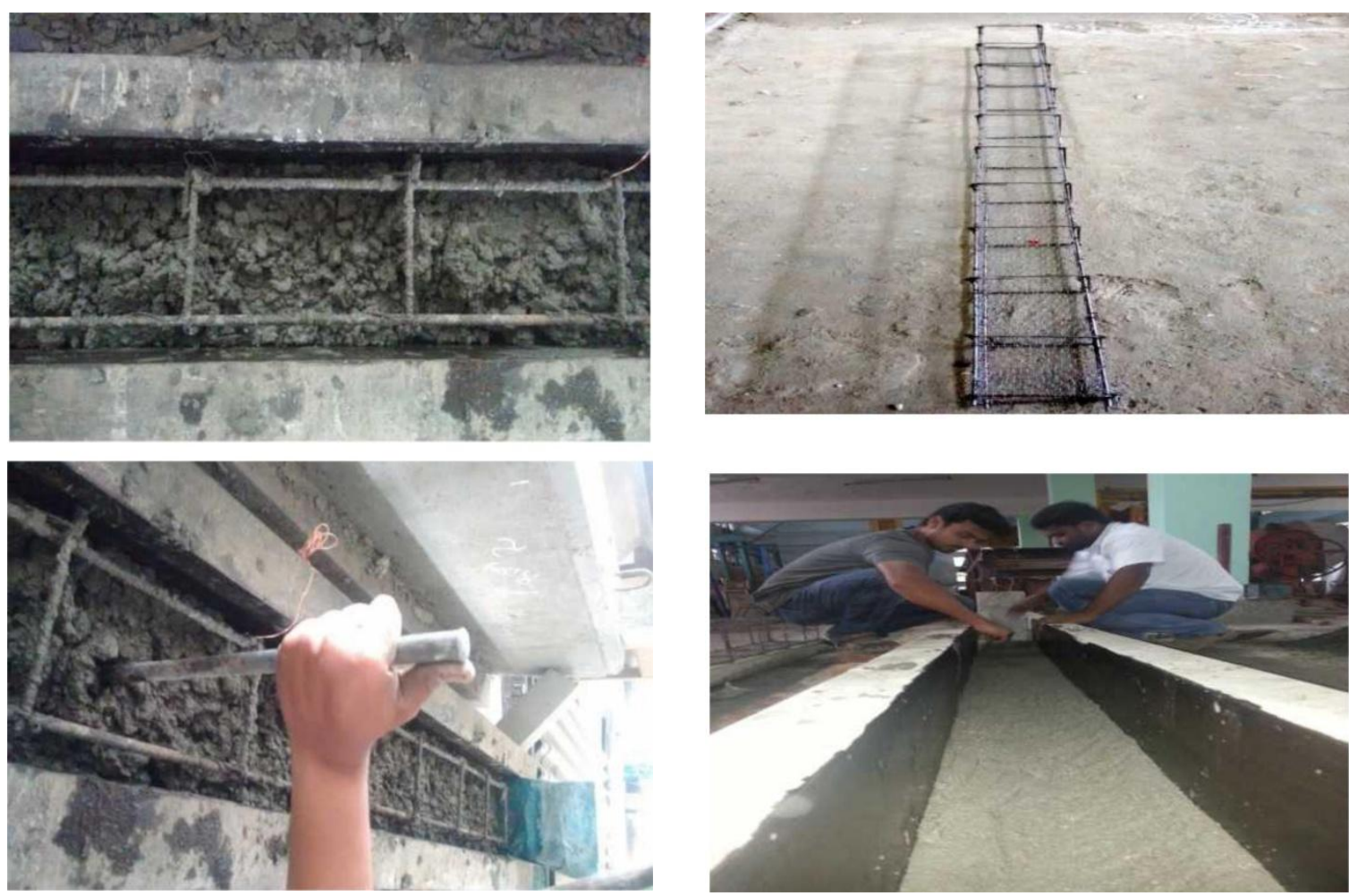

Fig.1. Casting of conventional and ferrocement hallow straight beams.
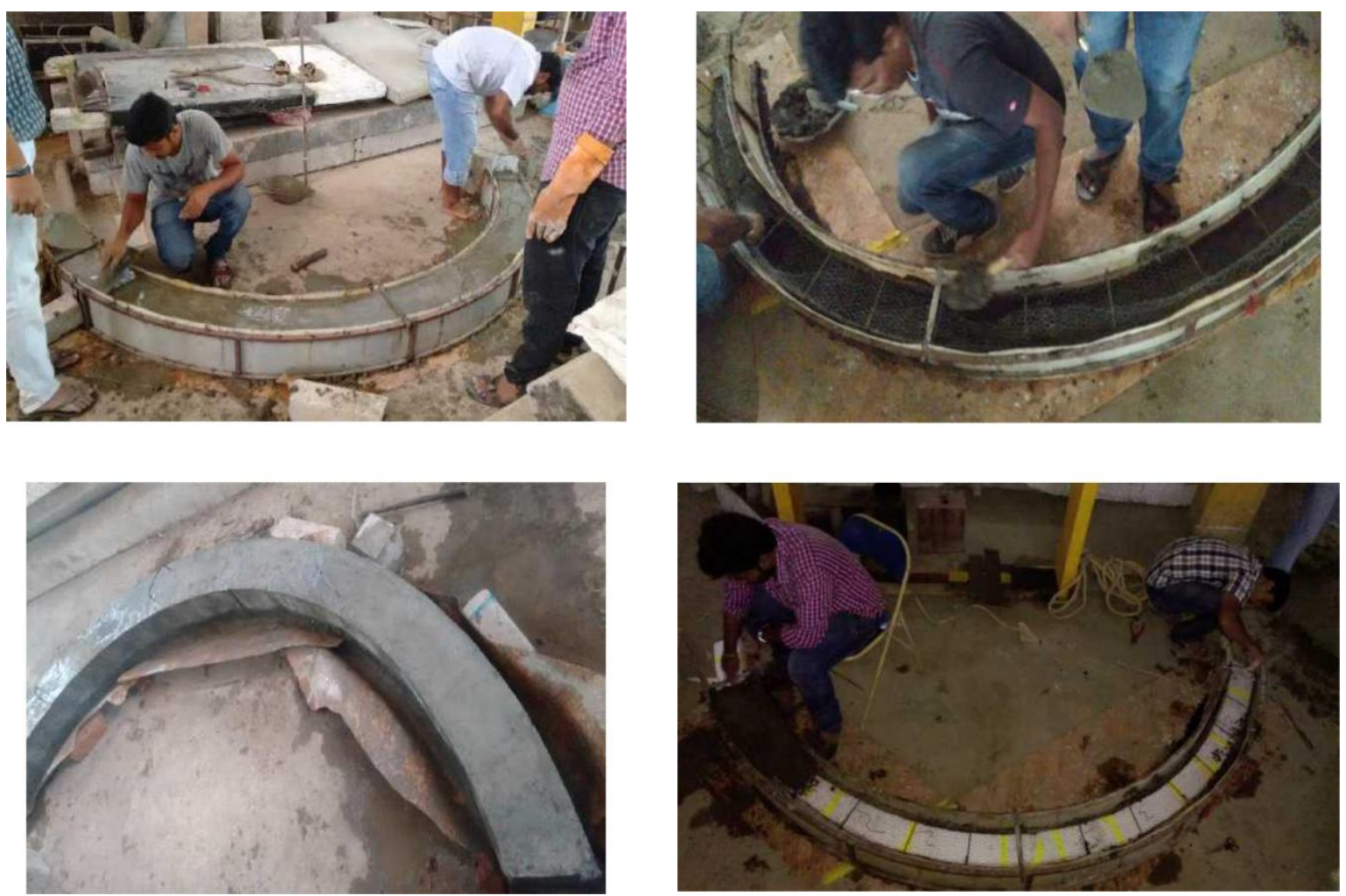

Fig.2. Casting of conventional and ferrocement hallow arch beams 


\section{Flexural Test on Test Beam Specimens}

Flexural tests are carried out on conventional RC beam and Ferrocement hollow beams for simply supported condition. The test results are presented in terms of load deflection behaviour, ultimate load, cracking load and crack pattern with respect to reinforced concrete beam and Ferrocement hollow beam.

\subsection{Test Specimens}

A series of four test specimens are chosen for the investigation and all are having a unique nominal sectional dimension of $200 \times 200 \mathrm{~mm}$ and the test beam have an effective span of $2500 \mathrm{~mm}$. The test specimens are divided into four categories according to their material combination listed as below.

$\checkmark$ Beam 1- B1 (Reinforced concrete beam)

$\checkmark$ Beam 2- B2 (Ferrocement hallow beam)

$\checkmark$ Beam 3- B3 (Reinforced concrete Arch beam)

$\checkmark$ Beam 4 -B4 (Ferrocement hallow Arch beam)

The typical details of the pattern of the reinforcement and cross section of the beams are shown in Fig 3 .
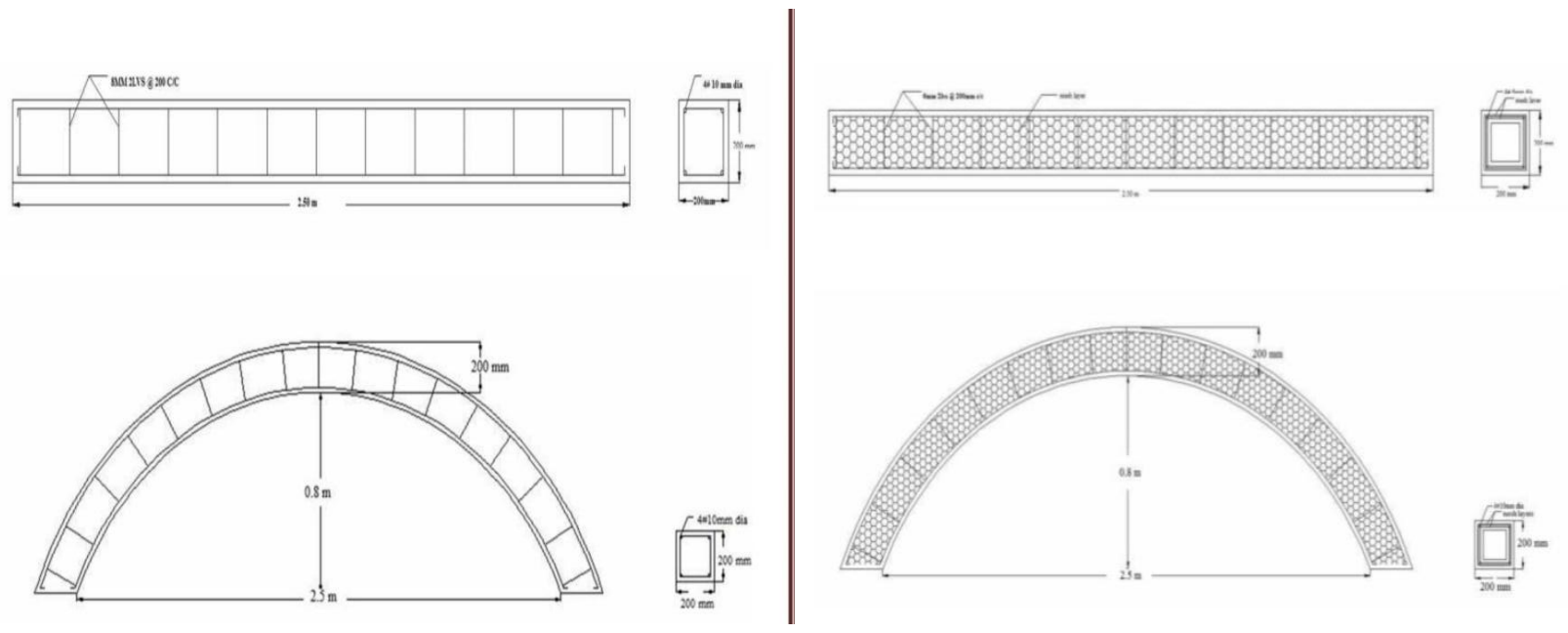

Fig 3. Geometry and reinforcement arrangement of conventional RC and Ferrocement hollow beams

\subsection{Test Programme}

The beams were supported on two supporting end blocks. The effective span of the beam was kept as $2400 \mathrm{~mm}$ and is tested under single point loading. One roller of $40 \mathrm{~mm} \Phi$ served as the loading point which was kept at the Centre of the beam. All beams were tested in the loading frame of capacity $300 \mathrm{KN}$ and the loading increment was applied to the test specimen from a $150 \mathrm{KN}$ capacity jack.

\section{Results}

5.1. Test results and discussions on workability, compressive strength, split tensile strength of concrete the test results of concrete are discussed for 7 and 28 days curing period.

\subsection{Flexural Behaviour of Conventional Concrete Beam and Ferrocement Hollow Beams}

Tests are conducted on four beams. The behaviour of the beams with tension reinforcements are tested under bending and the test results of each beam with respect to deflection, strains, cracking and 
ultimate loads, moment capacity, crack pattern are presented in the form charts. By using IS 456:2000 the necessary analytical calculations of ultimate moment, ultimate load, cracking loads, are presented.

\section{Load v/s Deflection}

The Conventional RC beam (B1) is tested in the laboratory for single point load system at the centre of beam, at a loading interval of $100 \mathrm{~kg}$; the corresponding deflections from dial gauges were recorded.

In the beam, before cracking, the slope of the curves was steep and closely linear. Once flexural cracks formed, a change in slope of the curve was observed and this slope remained fairly linear until yielding of the steel reinforcement took place.

The first crack obtained at a load of $15.696 \mathrm{KN}$, the corresponding dial gauge reading was $2.23 \mathrm{~mm}$

The ultimate load taken by the slab is $30.411 \mathrm{KN}$ and the corresponding deflection is $11.90 \mathrm{~mm}$ Load verses deflection curves were plot, fig .4 shows the details

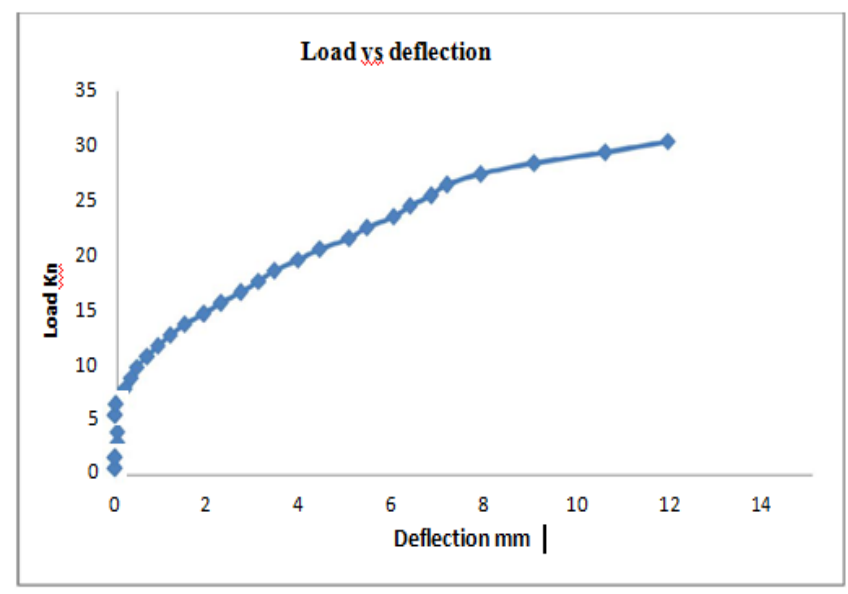

Fig.4 Variation of deflection with respect to load of Conventional RC beam

\section{Stress v/s Strain}

- The strain values of the strain gauges placed at centre were recorded at an incremental loading of $100 \mathrm{~kg}$

- The strain values obtained from all the 2 strain gauges were plotted with respect to stress as shown in fig.5.

- Strain values at first crack load were 71 and 10 for channels 1 and 2 respectively 


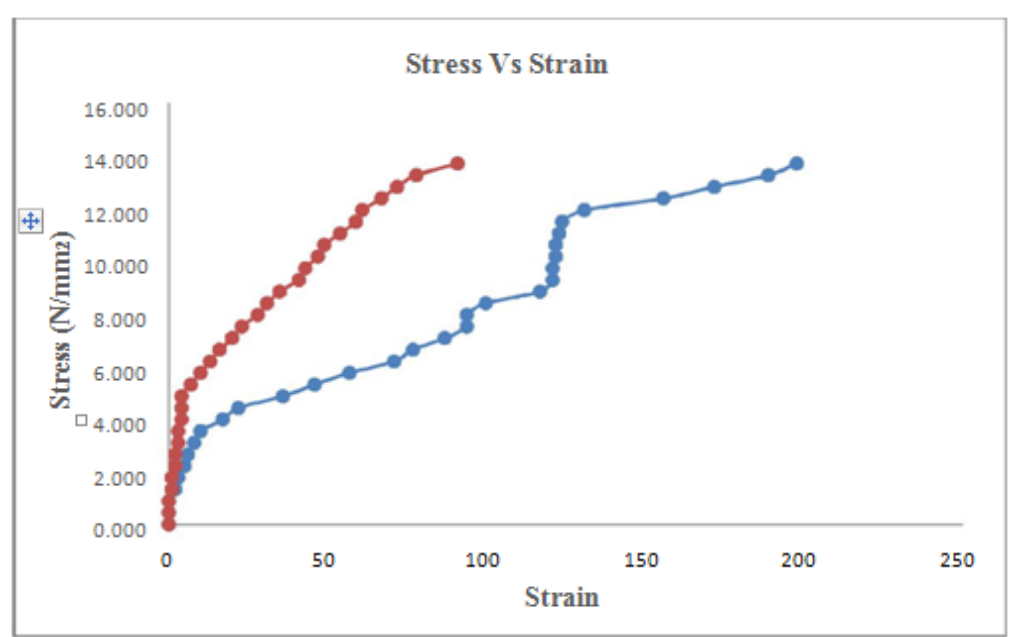

Fig.5 Variation of strain with respect to stress of Conventional RC beam

\subsubsection{Ferrocement Hollow Straight beam (B2)}

\section{Load v/s Deflection}

- The Ferrocement Hollow Straight Beam (B2) is tested in the laboratory for single point load system at the centre of beam, at a loading interval of $1000 \mathrm{~N} / \mathrm{mm} \mathrm{kg}$, the corresponding deflections from dial gauges were recorded.

- In the beam, before cracking, the slope of the curves was steep and closely linear. Once flexural cracks formed, a change in slope of the curve was observed and this slope remained fairly linear until yielding of the steel reinforcement took place.

- The first crack obtained at a load of $5.866 \mathrm{KN}$, the corresponding dial gauge reading was $1.70 \mathrm{~mm}$

- The ultimate load taken by the beam is $14.715 \mathrm{KN}$ and the corresponding deflection is 11.40 $\mathrm{mm}$.

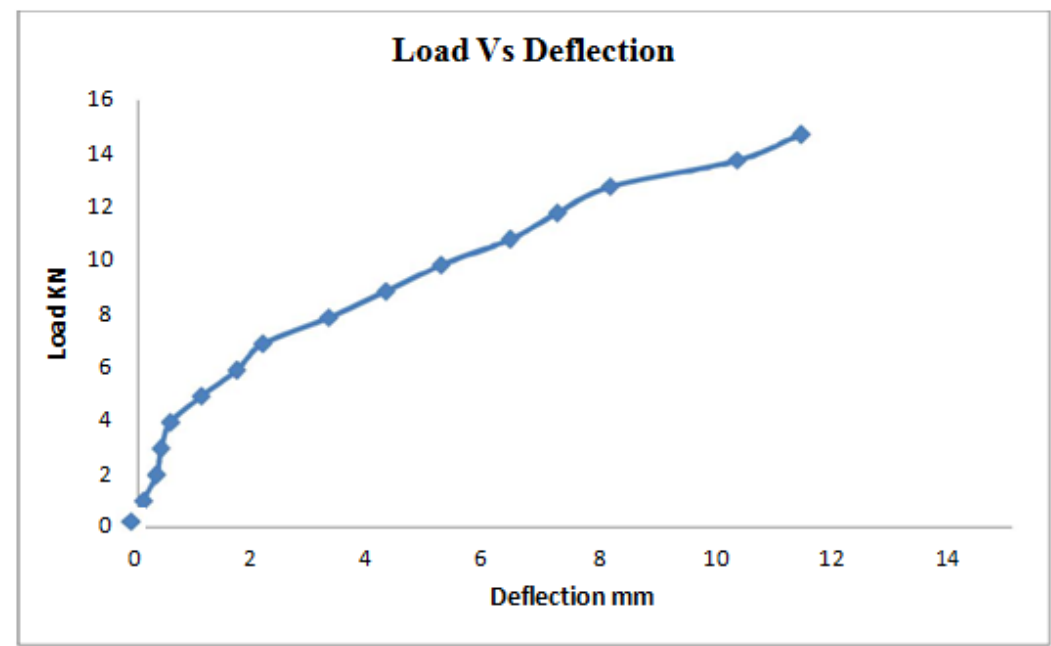

Fig.6 variation of deflection with respect to load of ferrocement hollow beam (b2)

\section{Stress v/s Strain}

The strain values of the strain gauges placed at centre were recorded at an incremental loading of $100 \mathrm{~kg}$ 
The strain values obtained from all the 2 strain gauges were plotted with respect to stress as shown in fig .7.

Strain values at first crack load were 18 and 07 for channels 1 and 2 respectively

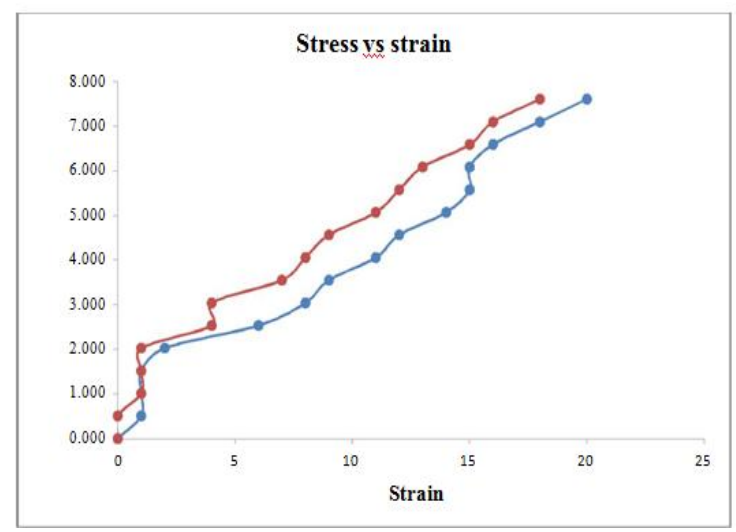

Fig.7 Variation of strain with respect to stress of Ferrocement Hollow Beam (B2)

\subsubsection{Conventional RC Arch Beam (B3)}

\section{Load v/s Deflection}

- The Conventional RC Arch beam (B1) is tested in the laboratory for single point load system at the centre of beam, at a loading interval of $100 \mathrm{~kg}$, the corresponding deflections from dial gauges were recorded.

- The first crack obtained at a load of $25.506 \mathrm{KN}$, the corresponding dial gauge reading was $1.22 \mathrm{~mm}$

- . The ultimate load taken by the slab is $103.005 \mathrm{KN}$ and the corresponding deflection is 10.72 $\mathrm{mm}$.

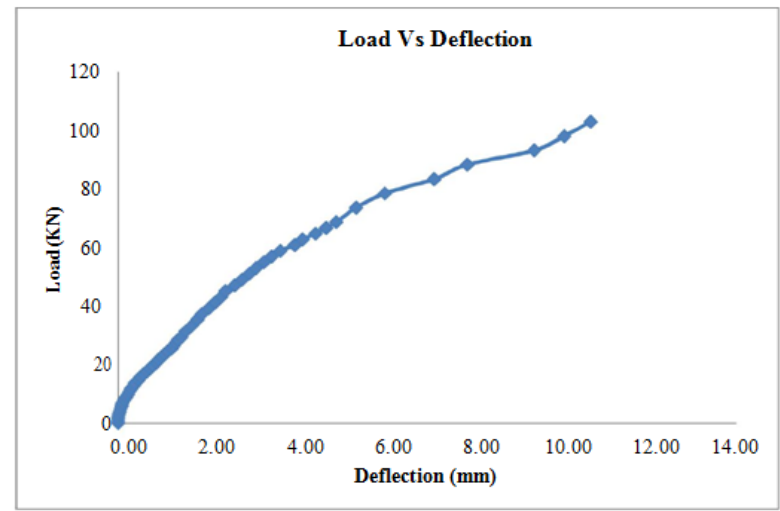

Fig. 8 Variation of strain with respect to stress of Ferrocement

Hollow Beam (B3) 


\section{Stress v/s Strain}

The strain values of the strain gauges placed at centre were recorded at an incremental loading of $100 \mathrm{~kg}$

The strain values obtained from all the 2 strain gauges were plotted with respect to stress as shown in fig. 9 .

Strain values at first crack load were 39 and 4 for channels 1 and 2 respectively

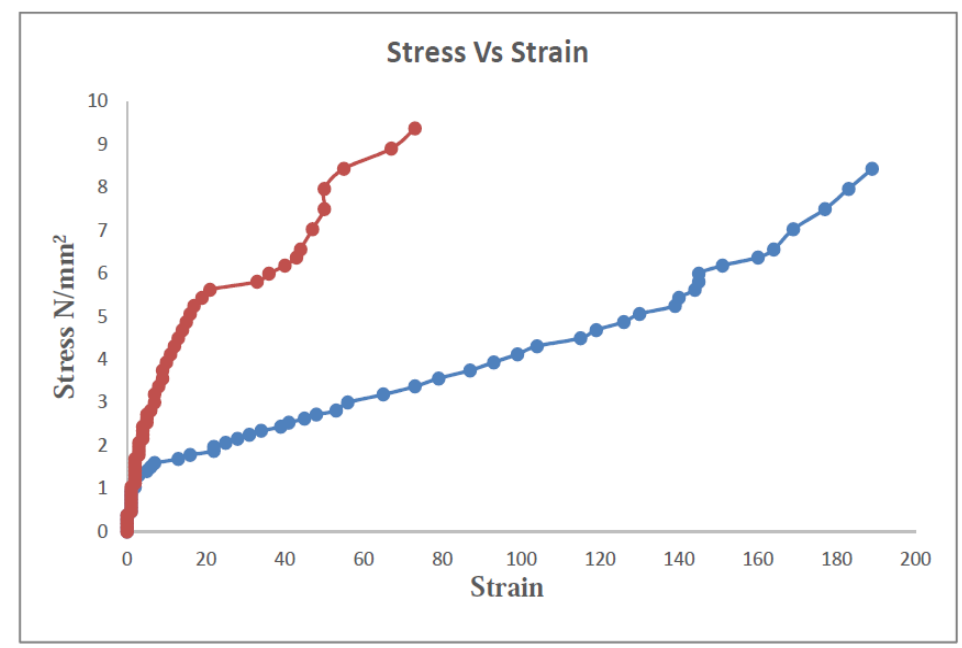

Fig. 9 Variation of strain with respect to stress of Conventional RC Arch beam (B3)

\subsubsection{FERROCEMENT HOLLOW ARCH BEAM (B4);}

\section{Load v/s Deflection}

The Conventional RC beam (B1) is tested in the laboratory for single point load system at the centre of beam, at a loading interval of $100 \mathrm{~kg}$ the corresponding deflections from dial gauges were recorded.

The first crack obtained at a load of $8.829 \mathrm{KN}$, the corresponding dial gauge reading was $1.20 \mathrm{~mm}$

The ultimate load taken by the slab is $39.240 \mathrm{KN}$ and the corresponding deflection is $6.91 \mathrm{~mm}$ 


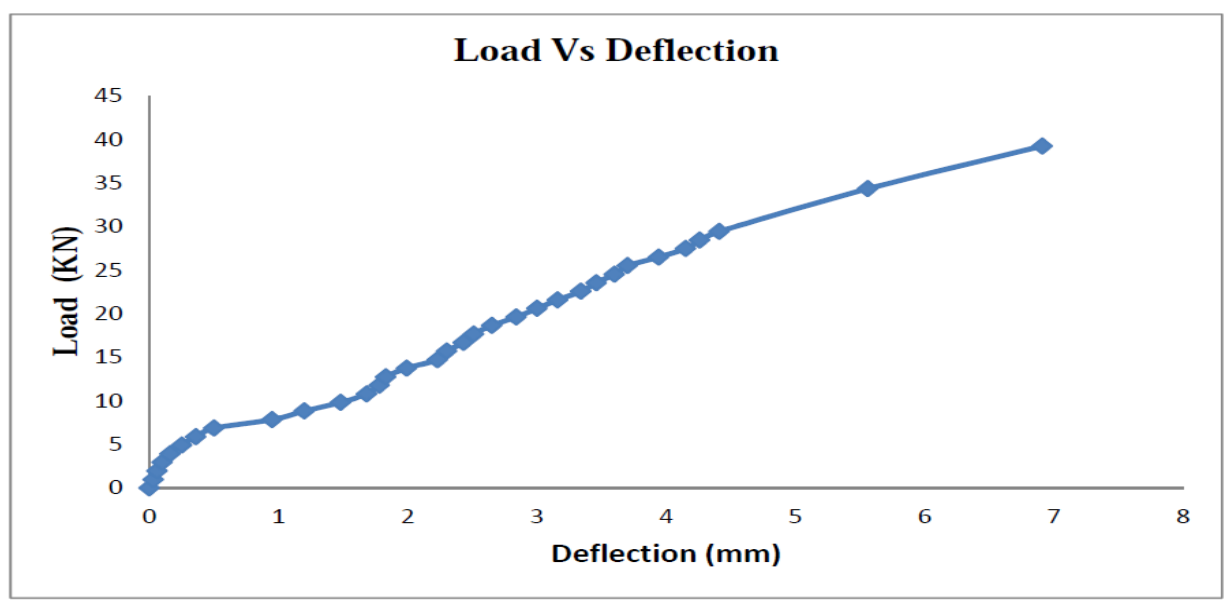

Fig.10 Variation of deflection with respect to load of Ferrocement Hollow Arch Beam(B4)

\section{Stress v/s Strain}

The strain values of the strain gauges placed at centre were recorded at an incremental loading of $100 \mathrm{~kg}$

The strain values obtained from all the 2 strain gauges were plotted with respect to stress as shown in fig 10.

Strain values at first crack load were 44 and 07 for channels 1 and 2 respectively

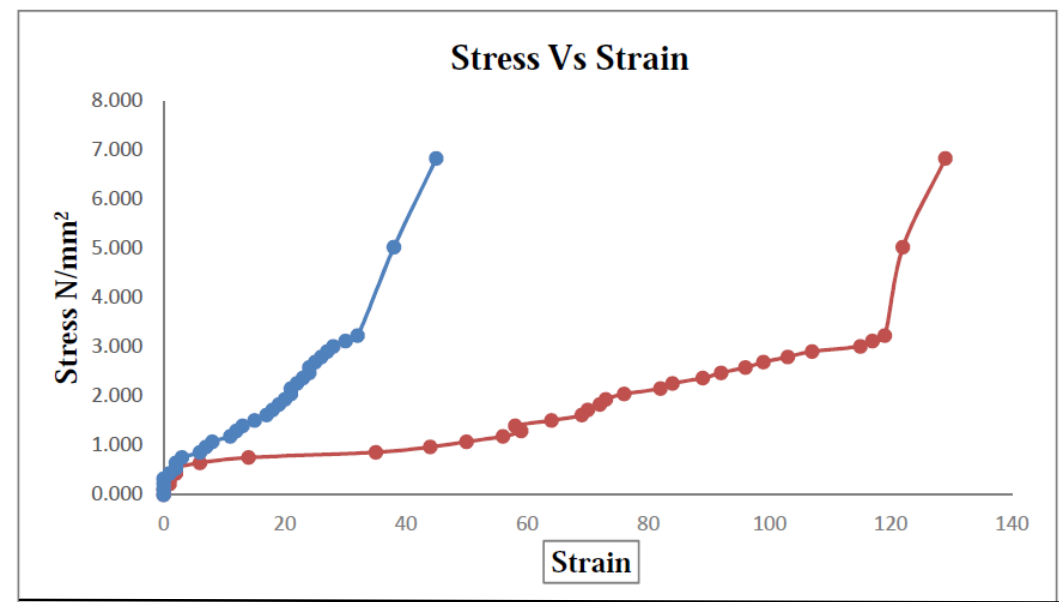

Fig.10 Variation of strain with respect to stress of Ferrocement Hollow Arch Beam (B4)

\section{Comparison of Ferrocement Hollow Beams with Conventional RC Beams}

\subsection{Comparison of Ferrocement hollow straight beam (B2) with conventional RC beam} (B1)

\subsubsection{Load and Deflection at Cracking Load:}

The result of cracking load and its corresponding deflection is tabulated below in table 1 
Table .1 Cracking load and its corresponding deflection of straight beams

\begin{tabular}{|l|l|l|l|l|}
\hline S1 No & Specimen & $\begin{array}{l}\text { Beam } \\
\text { Designation }\end{array}$ & $\begin{array}{l}\text { Cracking } \\
\text { load(kN) }\end{array}$ & $\begin{array}{l}\text { Deflection (mm) } \\
\text { @ cracking load }\end{array}$ \\
\hline 1 & Conventional RC beam & B1 & 15.696 & 2.23 \\
\hline 2 & $\begin{array}{l}\text { Ferrocement hallow straight } \\
\text { beam }\end{array}$ & B2 & 5.886 & 1.70 \\
\hline
\end{tabular}

From the Table 1, it is observed that the first crack appeared on the conventional RC beam (B1) when the applied load was $15.696 \mathrm{KN}$. In Ferrocement hollow straight beam the first crack load was 5.886 $\mathrm{KN}$.

Ferrocement hollow straight beam (B2) has shown first crack, when the applied load was $5.886 \mathrm{KN}$ which is $62.50 \%$ less when compared with Conventional RC beam (B1).

Ferrocement hollow straight beam (B2) have shown the deflection of $1.70 \mathrm{~mm}$ which is showing less deflection when compared with the Conventional RC beam of $2.23 \mathrm{~mm}$ of deflection at the appearance of first crack.

\subsubsection{Load and Deflection at Ultimate load}

The result of ultimate load and its corresponding deflection is tabulated below in table 2 .

Table. 2 Ultimate load and its corresponding deflection of straight beams

\begin{tabular}{|l|l|l|l|l|}
\hline S1 No & Specimen & $\begin{array}{l}\text { Beam } \\
\text { Designation }\end{array}$ & $\begin{array}{l}\text { Cracking } \\
\text { load }(\mathrm{kN})\end{array}$ & $\begin{array}{l}\text { Deflection (mm) } \\
\text { @ cracking load }\end{array}$ \\
\hline 1 & Conventional RC beam & B1 & 30.411 & 11.9 \\
\hline 2 & $\begin{array}{l}\text { Ferrocement hallow straight } \\
\text { beam }\end{array}$ & B2 & 14.715 & 11.4 \\
\hline
\end{tabular}

From the Table 2 it is observed that the failure appeared on the conventional RC beam (B1) when the applied load was $30.411 \mathrm{KN}$. In Ferrocement hollow straight beam the ultimate load was $14.715 \mathrm{KN}$. Ferrocement hollow straight beam (B2) has shown failure, when the applied load was $14.715 \mathrm{KN}$ which is $51.61 \%$ less when compared with Conventional RC slab.

Ferrocement hollow straight beam (B2) have shown the deflection of $11.40 \mathrm{~mm}$ which is showing less deflection when compared with the Conventional RC beam of $11.90 \mathrm{~mm}$ of deflection at the appearance of ultimate load.

\subsubsection{Comparison of Ferrocement hollow arch beam (B4) with conventional RC arch beam} (B3)

\subsubsection{Load and Deflection at Cracking Load}

The result of cracking load and its corresponding deflection is tabulated below in table 3 .

Table 3 Cracking load and its corresponding deflection of arch beams

\begin{tabular}{|l|l|l|l|l|}
\hline S1 No & Specimen & $\begin{array}{l}\text { Beam } \\
\text { Designation }\end{array}$ & $\begin{array}{l}\text { Cracking } \\
\text { load(kN) }\end{array}$ & $\begin{array}{l}\text { Deflection (mm) } \\
\text { @ cracking load }\end{array}$ \\
\hline 1 & Conventional RC arch beam & B3 & 25.506 & 1.22 \\
\hline 2 & $\begin{array}{l}\text { Ferrocement hallow arch } \\
\text { beam }\end{array}$ & B4 & 8.829 & 1.2 \\
\hline
\end{tabular}

From the Table 3 it is observed that the first crack appeared on the conventional RC arch beam (B1) when the applied load was $25.506 \mathrm{KN}$. In Ferrocement hollow straight beam the first crack load was $8.829 \mathrm{KN}$. 
Ferrocement hollow arch beam (B4) has shown first crack, when the applied load was $8.829 \mathrm{KN}$ which is $65.2 \%$ less when compared with Conventional RC arch beam (B3).

Ferrocement hollow arch beam have shown the deflection of $1.20 \mathrm{~mm}$ which is showing less deflection when compared with the Conventional RC beam of $1.22 \mathrm{~mm}$ of deflection at the appearance of first crack

\subsubsection{Load and Deflection at Ultimate load}

The result of ultimate load and its corresponding deflection is tabulated below in table 4 .

Table 4 Ultimate load and its corresponding deflection of arch beams

\begin{tabular}{|l|l|l|l|l|}
\hline S1 No & Specimen & $\begin{array}{l}\text { Beam } \\
\text { Designation }\end{array}$ & $\begin{array}{l}\text { Cracking } \\
\text { load(kN) }\end{array}$ & $\begin{array}{l}\text { Deflection (mm) } \\
\text { @ cracking load }\end{array}$ \\
\hline 1 & Conventional RC arch beam & B3 & 103.005 & 10.72 \\
\hline 2 & $\begin{array}{l}\text { Ferrocement hallow arch } \\
\text { beam }\end{array}$ & B4 & 39.24 & 6.91 \\
\hline
\end{tabular}

From Table 4, it is observed that the ultimate load taken by the Conventional RC arch beam (B3) is 103.005 KN and the ultimate load taken by the Ferrocement hollow arch beam (B4) was39.240 KN.

Ferrocement hollow arch beam (B4) has shown failure, when the applied load was $39.24 \mathrm{KN}$ which is $61.90 \%$ less when compared with Conventional RC arch beam (B3).Ferrocement hollow arch beam (B4) have shown the deflection of $6.91 \mathrm{~mm}$ which is showing less deflection when compared with the Conventional RC beam of $10.72 \mathrm{~mm}$ of deflection at the appearance of failure.

\subsection{Flexural Ductility Index}

Ductility is the measure of the element capacity to undergo inelastic behavior and absorb energy. Several forms of ductility are available. These include curvature, rotational, and displacement ductility. In this research, displacement ductility is investigated. Displacement ductility, $\mu_{\mathrm{d}}$, is defined as the ratio of deflection at ultimate moment to the deflection at first yield of the tensile reinforcement. In general, high ductility ratios indicate that a structural member is capable of undergoing large deflection prior to failure. Displacement ductility is given by

$$
\boldsymbol{\mu}_{\mathrm{d}}=\boldsymbol{\delta}_{\mathrm{u}} / \boldsymbol{\delta}_{\mathrm{y}}
$$

Table 5 Ductility Index

\begin{tabular}{|l|l|l|l|}
\hline Beam & $\boldsymbol{\delta}_{\mathbf{y}}, \mathbf{m m}$ & $\boldsymbol{\delta}_{\mathbf{u}}, \mathbf{m m}$ & $\boldsymbol{\mu}_{\mathbf{d}}=\boldsymbol{\delta}_{\mathbf{u}} / \boldsymbol{\delta}_{\mathbf{y}}$ \\
\hline B1 & 2.23 & 11.90 & 5.33 \\
\hline B2 & 1.70 & 11.40 & 6.70 \\
\hline B3 & 1.22 & 10.72 & 8.78 \\
\hline B4 & 1.20 & 6.91 & 5.75 \\
\hline
\end{tabular}




\section{Conclusions}

a) Conventional RC beams are showing better strength at first crack and also at ultimate failure when compared to Ferrocement beams.

b) Ferrocement hollow straight beam shows less deflection when compared with the Conventional RC beam.

c) Ferrocement hollow arch beam shows less deflection when compared with the Conventional RC arch beam.

d) The cost and weight of Ferrocement beams, both straight and arch type, is less when compared to normal RC type beams because of its higher volume of materials.

e) The bending stress calculations of straight and arch Ferrocement beams showed better results when compared to Conventional RC beams because of better ductile nature of Ferrocement.

f) Arch beams carries more load than the straight beams of same span. Hence arch beams can be used when higher loads are to be carried in lesser span length.

\section{References}

1. Adam J, Roman Building - Materials and Techniques, First Edition, B.T. Batsford Ltd, London, England,1994.

2. Heyman, J, The masonry arch, First Edition, Ellis Horwood Limited, West Sussex, England, 1982.

3. Dr.T.ChandraSekharRao, Dr.T.D.GunneswaraRao, Dr.N.V.RamanaRao, Ch.Rambabu, "An experimental study on ferrocement Box-beams under flexural loading", International Journal of Emerging Technology and Advanced Engineering, ISSN 2250-2459, Volume 2, Issue 9, September 2012.

4. Ezzat H Fahmy, Mohamed N Abou Zeid, Yousry B Shaheen, Ahmed A Abdelnaby, "Permanent ferrocement forms: A viable alternative for construction of concrete beams", 30th Conference on our world in concrete \& structures: 23 - 24 August 2005,Singapore.

5. Jain Joy, Rajesh Rajeev, "Effect of Reinforced Concrete Beam with Hollow Neutral Axis", International Journal for Scientific Research \& Development| Vol. 2, Issue 10, 2014, ISSN (online): 2321-0613.

6. Md Ihtesham Hussain1, Vaijanath Halhalli, P.M.B Raj kiran Nanduri, "Shear and flexural behavior of ferro cement deep Beams", International Journal of Research in Engineering and Technology eISSN: 2319-1163, pISSN: 2321-7308, Nov-2013.

7. Naveen G.M, Suresh G.S, “ Experimental study on light weight ferrocement beam under monotonic and repeated flexural loading", International journal of civil and structural engineering, volume 3, no 2, 2012, ISSN 0976 - 4399.

8. Ahmad Jabbar Hussain Alshimmeri, Hadi Nasir Ghadhban Al-Maliki, "Structural Behavior of Reinforced Concrete Hollow Beams under Partial Uniformly Distributed Load" Journal of Engineering, Number 7, Volume 20, July - 2014

9. Clive L. Dym, F.ASCE; and Harry E. Williams, "Stress and Displacement Estimates for Arches" journal of structural engineering (C) ASCE / January 2011.

10. Jason Salonga and Paul Gauvreau, "Span-to-rise ratios in concrete arches: threshold values for efficient behavior" ARCH'10 - 6th International Conference on Arch Bridges. 